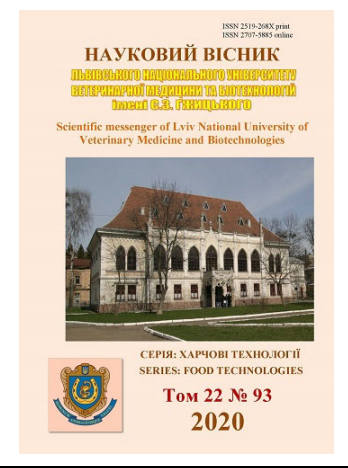

Науковий вісник Дьвівського національного університету ветеринарної медицини та біотехнологій імені С.3. Гжицького. Серія: Харчові технології

\author{
Scientific Messenger of Lviv National University \\ of Veterinary Medicine and Biotechnologies. \\ Series: Food Technologies
}

UDC 621.867

\title{
Increasing the productivity and accuracy of separation into fractions of a mixture of dissimilar disc-shaped products
}

\author{
A. L. Bespalov, I. G. Svidrak \\ National University “Lviv Polytechnic”, Lviv, Ukraine
}

Article info

Received 07.02.2020

Received in revised form 10.03.2020

Accepted 11.03.2020

National University "Lviv Polytechnic", S. Bandera Str., 12, Lviv, 790013, Ukraine.

Tel.: +38-066-229-50-87 E-mail:svidrak99@gmail.com
Bespalov, A. L., \& Svidrak, I. G. (2020). Increasing the productivity and accuracy of separation into fractions of a mixture of dissimilar disc-shaped products. Scientific Messenger of Lviv National University of Veterinary Medicine and Biotechnologies. Series: Food Technologies, 22(93), 6165. doi: $10.32718 /$ nvlvet-f9311

During collection and counting of coins or tokens, the mixture must be divided into fractions by denomination. Methods of separating coins and existing designs of equipment for separation are considered. It is revealed that the existing designs of vibration devices for sorting disc-shaped parts have low productivity, as well as a fairly large sorting error. A set of elements affecting the performance and efficiency of vibration separators with electromagnetic drives is considered. A new separator design based on a vibrating hopper feeder is proposed. Changed the geometry of the working body and parameters of other elements that affect the accuracy of the separation process and its performance. A prototype of the vibration separator was made according to the project of the proposed design. Experimental studies of the separation process on this separator were carried out to identify the parameters of the accuracy of separation of a mixture of coins with a nominal value of one and two kopecks at different speeds of the process. The research was conducted on two batches of 1000-piece coins with a nominal value of one and two kopecks. Both batches were mixed, the mixture was loaded into the separator hopper in bulk and the separation process was carried out, at the end of which the number of coins of both denominations was determined, which were not in their own separate batches. For each transport speed, fifty measurements were made and the arithmetic mean value of the indicator was determined. It was found that the absolute accuracy of separation on this device is achieved at a speed of vibration transport up to $0.5 \mathrm{~m} / \mathrm{s}$. When upgrading the separation zone using compressed air jets, absolute separation accuracy is achieved at a speed of up to $1 \mathrm{~m} / \mathrm{s}$. It is established that the new design of the vibration separator proposed by the authors significantly increases the productivity of the sorting process by denominations (diameters) of the coin mixture into fractions with absolute separation accuracy. This device can also be used for sorting small parts or products that have the shape of disks (washers, rondels, buttons, etc.).

Key words: vibrating hopper feeder; measuring Windows; coin mix; vibro-transport speed; hyperboloid torsion.

\section{Підвищення продуктивності та точності сепарування на фракції суміші різнорозмірних дископодібних виробів}

\author{
А. Л. Беспалов, І. Г. Свідрак
}

Національний університет “Львівська політехніка”, м. Львів, Украӥна

Під час інкасаиії та обліку монет або касових жетонів часто виникає необхідність розділити їх суміш на фракиї за номіналами. Розглянуто способи сепарування монет та існуючі конструкції обладнання для розділу суміші об'єктів на фракції за розмірами. Виявлено, щцо існуючі конструкиії вібраційних пристроїв для сортування дископодібних деталей мають невисоку продуктивність, а також достатньо велику похибку сортування. Розглянуто комплекс, елементів, щзо впливають на продуктивність та ефективність роботи вібраційних сепараторів з електромагнітними приводами. Запропоновано нову конструкцію сепаратора на основі вібраційного бункерного живильника, де змінено геометрію робочого органа та деяких параметрів інших його елементів, щчо впливають на точність процесу сепарування та його продуктивність. За проектом запропонованої конструкції виготовлено 
дослідний взірецьь вібраџійного сепаратора. Проведено експериментальні дослідження процесу сепарування на изьому сепараторі з метою виявлення параметрів точності сепарування сумімі монет номіналом одна та дві копійки при різних швидкостях процесу. Дослідження проводились на двох партіях монет розміром по 1000 штук номіналом у одну та дві копійки. Обидві партії змішувались, суміш завантажувалась у бункер сепаратора навалом і проводився процес сепарування, по закінченню якого визначалась кількість монет обох номіналів, що потрапили не в свої відсепаровані партії. Для кожної швидкості транспортування було проведено по п'ятдесят вимірів і визначено середньоарифметичне значення показника. 3'ясовано, шуо абсолютна точність сепарування на иьому пристрої досягається при швидкості вібротранспортування до 0,5 м/с. При невеликій модернізації зони сепарування з використанням струменів стисненого повітря абсолютна точність сепарування досягається при швидкості вібротранспортування до $1 \mathrm{M} / \mathrm{c}$. Встановлено, щз запропонована авторами нова конструкція вібраційного сепаратора значно збільшує продуктивність процесу сортування за номіналами (діаметрами) сумімі монет на фракції при абсолютній точності сепарацї. Цей пристрій також може бути застосований для сортування дрібних деталей або виробів, щуо мають форму дисків (иайб, ронделів, гудзиків тощзо).

Ключові слова: вібраційний бункерний живильник; вимірювальні вікна; суміш монет; швидкість вібротранспортування; гіперболоїдний торсіон.

\section{Ветуп}

Під час інкасації та обліку монет або касових жетонів часто виникає необхідність розділити їх суміш на фракції за номіналами (діаметрами). Широкого застосування для здійснення даної операції набули вібраційні сепаратори, які розроблені на основі вібраційних бункерних живильників, що приводяться у дію електромагнітними віброзбудниками. Ці пристрої можуть також бути використані для сортування дрібних деталей або виробів, що мають форму дисків (шайб, ронделів, гудзиків тощо). При використанні таких сепараторів для сортування монет особлива увага приділяється точності їхнього сортування (Bespalov et al., 2000).

Актуальність теми. Аналіз літературних джерел (Kolosov \& Vlasov, 1976) виявив, що існуючі конструкції механічних сепараторів та сепараторів на основі вібраційних бункерних живильників неспроможні забезпечити високої точності сортування при високій продуктивності процесу, а також за допомогою них неможливо розділяти суміш, що складається з більш ніж двох компонентів. Одним з пристроїв для розділу такої суміші $є$ пристрій для сортування виробів (Rabinovich et al., 1965), що являє собою вібраційний бункер, який складається 3 віброзбудника і чаші, на боковій поверхні якої вздовж транспортуючого лотка $\epsilon$ вихідні вікна у формі деталей, які мають відділятися. Недоліками цього пристрою є низька продуктивність та невисока надійність сортування. Низька продуктивність пристрою обумовлюється тим, що деталь, яка рухається по лотку віброживильника, має випасти через вікно, що має форму деталі. Це можливо в цій конструкції тільки при малих швидкостях (до 0,1 м/с) транспортування. При збільшуванні швидкості деталі потрібних розмірів не встигають випасти через ці вікна, а протягуються далі потоком решти деталей, що призводить до втрати цим пристроєм здатності виконувати свою пряму функцію - сортування деталей. Крім того, деталі по лотку віброживильника рухаються у декілька шарів, що не дає змоги меншим деталям 3 верхнього шару випасти через вікна, якщо під ними $\epsilon$ більші деталі, що перекривають ці вікна. Це призводить до того, що менші деталі проносяться потоком деталей далі та мають можливість випасти через вікна, призначені для деталей, більших за розміром. Все це суттєво знижує надійність і точність процесу сортування. Існуючі конструкції вібраційних пристроїв для сортування дископодібних деталей мають невисоку продуктивність, а також достатньо велику похибку сортування, тому створення нових конструкцій сепараторів, які будуть мати велику продуктивність і точність сортування, є актуальним.

Мета $i$ завдання дослідження. Для підвищення продуктивності процесу сортування суміші монет, посилення надійності роботи пристрою, збільшення діапазону типорозмірів монет, на які одночасно розділяється суміш монет при сортуванні, та зменшення похибки сортування необхідно змінити конструкцію бункера вібраційного сепаратора та його окремих елементів, що впливають на процес сортування.

\section{Матеріал і методи досліджень}

Для того, щоби визначити перевагу розробленого устаткування порівняно з існуючим, необхідно виготовити дослідний взірець вібраційного сепаратора і на ньому провести експериментальні дослідження точності сепарування монет на різних швидкостях транспортування монет і визначити залежність точності сепарування від швидкості транспортування монет

\section{Результати та їх обговорення}

Одним з перспективних пристроїв для розділу суміші монет $є$ сепаратор, виконаний на основі вібраційного бункерного живильника 3 направленими гвинтовими коливаннями та конічним бункером у вигляді чаші, на внутрішній поверхні якого закріплено гвинтовий транспортувальний лоток, вздовж якого прорізані вимірювальні вікна шириною трошки більшою за діаметр монети найменшого діаметра із сумішi.

Конструктивна схема цього пристрою зображена на рис. 1. Він складається з конічного бункера 1 та реактивного вантажу 2, що зв'язані між собою пружною системою 3 , котра являє собою гратчастий гіперболоїдний торсіон з нахиленими пласкими пружинами, та електромагнітного вібраційного приводу, якір якого 4 приєднано до верхнього фланцю торсіона, а електромагніт 5 - до нижнього. Всередину бункера вкладено і приклеєно гумову робочу поверхню 6, на якій виконано гвинтовий транспортуючий лоток. На боковій поверхні бункера 1 прорізані вимірювальні вікна 7, що розташовані вздовж лотка. Кількість вікон залежить від кількості номіналів монет у суміші. Бо- 
кові стінки вікон зроблено нахиленими в бік переміщення монет.

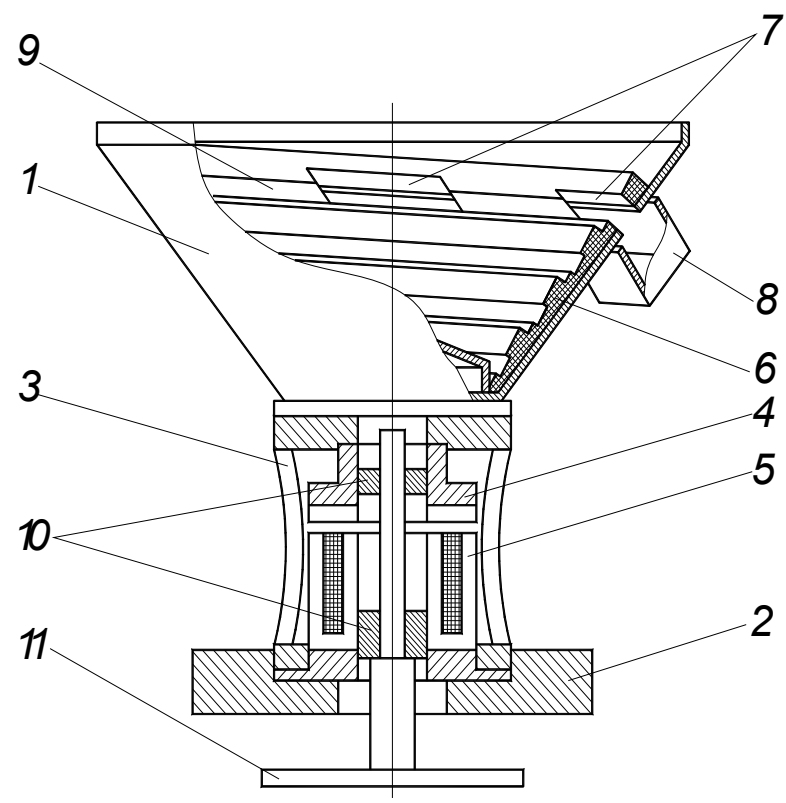

Рис. 1. Конструктивна схема вібраційного сепаратора

Форму вимірювальних вікон 7 зображено на рис. 2. Вимірювальні вікна 7 мають різну висоту, тому що нижній край вікон зроблено нижче від центру ваги найменшої монети, що розміщена на доріжці, і тому в усіх вікон він розташований на однаковій відстані від опорної поверхні лотка, а верхній край кожного вікна, що призначено для випадання певної монети, зроблено вище від верхнього краю монети, що розташована на лотку. Всі вікна розташовані вздовж лотка послідовно за ходом переміщення монет в порядку зростання висоти їх проміжку. Із зовнішнього боку бункера 1 в зоні кожного 3 вікон 5 розташовано відвідні лотки 8. На боковій внутрішній поверхні чаші зроблено еквідистантне до опорної поверхні лотка заглиблення 9 (рис. 2).

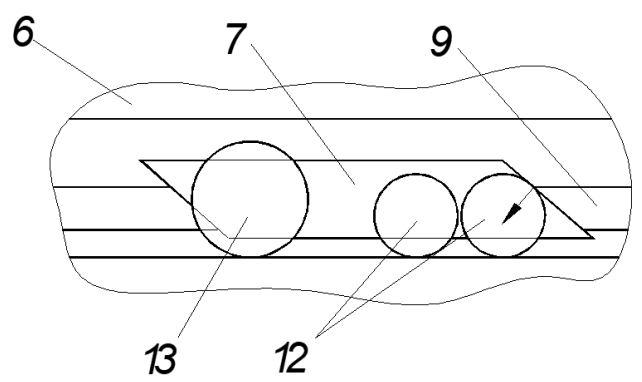

Рис. 2. Геометрія вимірювальних вікон

Верхній край заглиблення 9 зроблено нижче від верхнього краю найменшої монети, що розташована на лотку. Форму і розташування заглиблення 9 зображено на рис. 2 та 4. Всю конструкцію через амортизатори 10 встановлено на нерухомій основі 11 .

Пристрій працює таким чином. При включенні електромагнітного приводу бункер 1 зі вставкою 6 приводиться у коливний рух. Завдяки направленій вібрації монети різного розміру, що насипані до бункера 1 навалом, вишиковуються вздовж поверхні лотка і транспортуються по гвинтовій траєкторії догори. Монети розташовуються площиною на боковій конічній поверхні вставки 6, а кантом опираються на опорну площину лотка. Вони розташовуються на доріжці в один шар за рахунок того, що ширина опорної поверхні лотка зроблена рівною товщині найменшої монети. Транспортуючись по гвинтовому лотку в один шар, монети проходять мимо вимірювальних вікон 7. Досягнувши першого вікна, більші за розміром монети 13 транспортуються далі, а найменші за діаметром монети 12 (рис. 3) під дією сили ваги i відцентрової сили випадають через вікно 7 з бункера 1 і по відвідному лотку 8 направляються до відповідної тари.

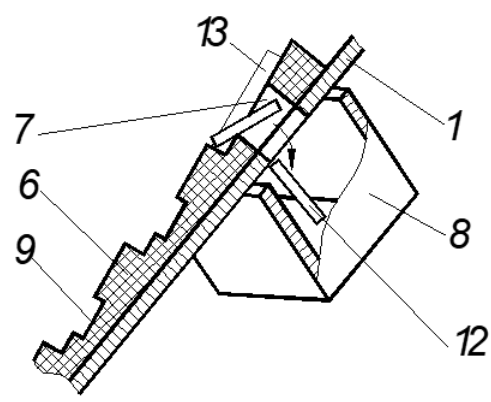

Рис. 3. Схема процесу сепарації

Таким чином, після першого вікна на доріжці залишається шар монет всіх наступних розмірів, за винятком найменших. При досягненні монетами наступного за ходом і за величиною проміжку вікна 7 відбувається випадання через нього наступної за розміром фракції монет. Цей процес відбувається послідовно у всіх вимірювальних вікнах 7, кількість яких дорівнює кількості фракцій монет, що сортуються. Таким чином, представлений пристрій дозволяє розсортувати суміш монет різного розміру на всі фракції, що до неї входять.

Розглянемо положення монети на лотку конічного бункера, яка не має заглиблення 9 на боковій поверхні 6 (рис. 4 а). Монета опирається торцем на гвинтовий лоток, а площиною лежить на конічній поверхні бункера. Завдяки тому, що монета пласка, а поверхня бункера має певний радіус, бокова поверхня монети не може щільно прилягати до цієї поверхні. Монета, таким чином, дотикається до поверхні бункера тільки двома боковими точками і тому вона може повертатися відносно осі, що проходить через ці точки на певний кут, який залежить від відстані між серединою монети та поверхнею чаші й діаметра монети. Таким чином, монета може займати два крайні положення: перше, коли вона опирається боковими точками та нижнім краєм до поверхні бункера і одночасно нижнім торцем на гвинтовий лоток, і друге, коли вона опирається боковими точками та верхнім краєм до поверхні бункера і одночасно нижнім торцем на гвинтовий лоток. Отже, в першому положенні монета нижнім краєм щільно прилягає до поверхні чаші i, таким чином, повністю опирається на гвинтовий лоток. Це дає гарантію, що монета не буде спадати 3 цього лотка. У другому положенні монета верхнім 
краєм щільно прилягає до поверхні бункера, а нижній край відступає від поверхні на певну величину, яка може бути рівною або більшою за ширину лотка. У такому випадку ця монета спадає з лотка

В представленому пристрої за рахунок наявності заглиблення 9 (рис. 4 б) монета 12 опирається боковою поверхнею на конічну частину робочої поверхні 6 бункера 1 чотирма точками, що надає їй стійкості і однозначного стійкого розташування на ній. Цей фактор сприяє доброму заповненню лотка монетами, що своєю чергою сприяє збільшенню продуктивності процесу сортування. Крім того, стійке положення монети на поверхні бункера дає можливість зробити ширину опорного буртика рівною товщині найменшої монети в суміші і отримати на доріжці одношаровий ряд різного розміру виробів дископодібної форми, що дозволяє збільшити надійність процесу сортування монет.

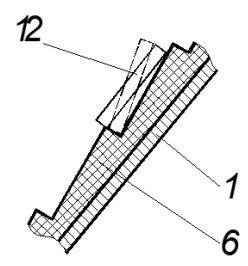

Puc. $4 a$

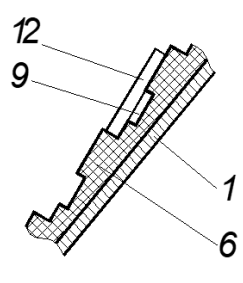

Puc. 46
Рис. 4. Варіанти положення монети на лотку

При вібротранспортуванні вироби не рухаються плавно по лотку вібраційного бункерного живильника, а здійснюють мікропольоти щодо вібруючого лотка (Silin, 1986). Величина мікропольотів збільшується із збільшенням амплітуди коливань лотка. Тому для збільшення надійності сортування вимірювальні вікна мають довжину, що перевищує величину одного мікропольоту монети, яка транспортується. Це виключає можливість прольоту монетою вимірювального вікна, що забезпечує абсолютну надійність випадання іiі в призначене для даного типорозміру вікно. Але момент відриву монети від лотка і момент зустрічі іiї з ним є подіями випадковими. Тому виникає можливість співударяння монети при транспортуванні 3 боковою стінкою вимірювального лотка в момент зустрічі. Для того, щоб монета в цьому разі не відбивалася хаотично, що може привести до випадання іiі в будь-яке 3 вікон і тим самим зменшити надійність сепарування, перша по ходу переміщення монет стінка вимірювального вікна зроблена нахиленою в бік переміщення монет (рис. 2). Це дає гарантію, що монета при співударянні з цією стінкою буде відкидатися тільки донизу, тобто назад до бункера, і тим досягається висока надійність сортування монет.

На розробленому за описаною вище технологією і виготовленому вібраційному сепараторі було проведено експериментальні дослідження залежності точності сепарування від швидкості транспортування монет по доріжці бункера. Дослідження проводились на двох партіях монет розміром по 1000 штук номіналом у одну та дві копійки. Обидві партії змішувались, суміш завантажувалась у бункер сепаратора навалом і проводився процес сепарування, по закінченню якого визначалась кількість монет обох номіналів, що потрапили не в свої відсепаровані партії. Для кожної швидкості транспортування було проведено по п'ятдесят вимірів і визначено середньоарифметичне значення показника. Результати досліджень наведені у таблиці.

\section{Таблиця 1}

Залежність точності сепарування монет від швидкості їх транспортування по лотку

\begin{tabular}{cccccc}
\hline $\begin{array}{c}\text { Швидкість транс- } \\
\text { портування (м/с) }\end{array}$ & $\begin{array}{c}\text { Відсортовані монети } \\
\text { номіналом у 1 коп. }\end{array}$ & $\begin{array}{c}\text { Похибка } \\
\text { сортування }\end{array}$ & $\begin{array}{c}\text { Відсортовані монети } \\
\text { номіна-лом у } 2 \text { коп. }\end{array}$ & $\begin{array}{c}\text { Похибка } \\
\text { сортування }\end{array}$ & $\begin{array}{c}\text { Відносна похибка } \\
\text { сортування (\%) }\end{array}$ \\
\hline 0,1 & 1000 & 0 & 1000 & 0 & 0 \\
0,2 & 1000 & 0 & 1000 & 0 & 0 \\
0,3 & 1000 & 0 & 1000 & 0 & 0 \\
0,4 & 1000 & 0 & 1000 & 0 & 0 \\
0,5 & 1000 & 0 & 1000 & 0 & 0,05 \\
0,6 & 999,5 & 0,5 & 1000 & 0 & 0,05 \\
0,7 & 999,5 & 0,5 & 1000 & 0 & 0,1 \\
0,8 & 999 & 1 & 1000 & 0 & 0,5 \\
0,9 & 995 & 5 & 1000 & 0 & 0,5 \\
\hline
\end{tabular}

Аналізуючи результати дослідження, було встановлено, що представлений варіант сепарувального пристрою забезпечує абсолютну точність сепарування при швидкості переміщення до 0,5 м/с, а при збільшенні швидкості - 3'являються похибки сепарування. Це виникає через те, що монети на такій швидкості не встигають випасти через вимірювальні вікна, які мають певну довжину. Збільшення довжини вікон приводить до порушення жорсткості стінок чаші і виникнення паразитних коливань, які порушують режими вібротранспортування. Для прискорення процесу випадання монет через вимірювальні вікна були встановлені пневматичні сопла 14 для подачі струменя стисненого повітря, розташування яких показано на рис. 5. Завдяки додатковому зусиллю, що утворюється дією повітряного струменю на монету, процес випадання монет через вікна скорочується і сепарування можна здійснювати при швидкостях транспортування, близьких до 1 м/с. Аналогічні попереднім експериментальні дослідження, що були проведені на такому сепараторі, показали, що на таких швидкостях було отримано абсолютну точність сепарації монет. 


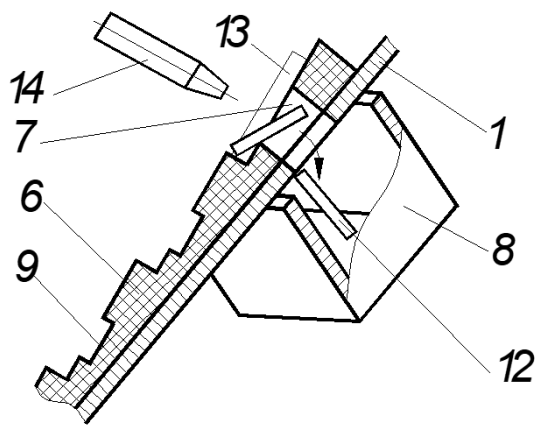

Рис. 5. Модернізована схема процесу сепарації

\section{Висновки}

За рахунок наявності на на внутрішній конічній поверхні 6 бункера 1 заглиблення 9, що еквідистантне опорній поверхні лотка, яка має ширину, рівну товщині найменшої монети, на лотку утворюється один шар монет різного розміру, які транспортуються вздовж вимірювальних вікон 7, що повністю виключає можливість проносу монет мимо передбачених для них вимірювальних вікон і тим самим створює абсолютну надійність сортування.

Розміщення вимірювальних вікон в порядку зростання їх висоти по ходу переміщення монет дозволяє повністю розділити суміш монет на всі розмірні фракції, якщо кількість вікон дорівнює кількості розмірних фракцій монет.
Таким чином, при наявності у сепарувальному пристрої всіх вищерозглянутих елементів можна 3 його допомогою здійснювати сортування суміші монет при лінійній швидкості транспортування їх по лотку до 0,5 м/с при абсолютній надійності процесу сортування, а на швидкісних конструкціях, що оснащені соплами для подачі стисненого повітря, - швидкість транспортування може бути збільшена до $1 \mathrm{~m} / \mathrm{c}$.

\section{References}

Bespalov, A. L. Shenbor, V. S., \& Mel'nychuk, I. M. (2000). Avtomatyzovanyj kompleks obliku monet, Respublikans'kyj mizhvidomchyj naukovotehnichnyj zbirnyk "Avtomatyzacija vyrobnychyh procesiv u mashynobuduvanni ta pryladobuduvanni", 35 (in Ukrainian).

Kolosov, E. M., \& Vlasov, O. M. (1976). Ustrojstvo dlja sortirovki monet po diametru, A.S. № 503265, B. I. № 6 (in Russian).

Povidajlo, V. A., \& Bespalov, A. L. (1991). Ustrojstvo dlja separacii, schjota i rasfasovki monet, AS № 1702405, B. I. № 48 (in Russian).

Rabinovich, A. N., Shereshevskij, N. I., Vasilenko, I. N., \& Matvejchuk, V. S. (1965). Sborochnye mashiny i linii nepreryvnogo dejstvija, Kiev (in Russian).

Silin, R. I. (1986). Avtomaticheskie sistemy dlja scheta i rasfasovki melkih izdelij "Vishha shkola". Kiev, 117119 (in Russian). 